\title{
Implementasi Metode Graphic Rating Scale (GRS) Pada Aplikasi Penilaian Kinerja Relawan Bulan Sabit Merah Indonesia Cabang Surabaya Berbasis Website
}

\author{
Yudistira Yusonanda ${ }^{1}$, M.J. Dewiyani Sunarto ${ }^{2}$, Norma Ningsih ${ }^{3}$ \\ 1,2,3 Jurusan Sistem Informasi \\ Universitas Dinamika \\ J1. Raya Kedung Baruk 98 Surabaya, 60298 \\ Email : yusonanda@gmail.com ${ }^{1}$, dewiyani@dinamika.ac.id ${ }^{1}$, norma@dinamika.ac.id ${ }^{3}$
}

\begin{abstract}
Abstrak : Penilaian kinerja adalah suatu penilaian yang dilakukan kepada pihak manajemen perusahaan baik para karyawan maupun manajer yang selama ini telah melakukan pekerjaannya. Bulan Sabit Merah Indonesia Surabaya atau yang disingkat BSMI adalah sebuah organisasi yang bergerak dibidang kemanusiaan. Saat ini BSMI Surabaya masih belum memiliki sistem penilaian kinerja relawan serta kurangnya evaluasi untuk penilaian kinerja yang bisa membuat para relawan dapat melakukan kesalahan-kesalahan atau tidak menerapkan tugas sesuai diklat atau pelatihan yang telah diajarkan sebelumnya tanpa memperhatikan aturan yang telah ditetapkan. Berdasarkan masalah tersebut, maka diusulkan sebuah solusi aplikasi penilaian kinerja relawan berbasis website dengan menggunakan metode Graphic Rating Scales (GRS) yaitu metode penilaian yang membagi 5 kategori penilaian untuk setiap factor penilaian, penilaian dengan metode ini seuai dengan kebutuhan organisasi. Aplikasi dapat menemukan nilai total untuk setiap 3 kali kejadian dari relawan tersebut dan memperlihatkan grafik kinerja relawan dari tahun ke tahun untuk mengevaluasi dan melihat peningkatan atau penurunan kinerja relawan serta terdapat fitur laporan akhir berupa rangking dari seluruh relawan sesuai urutan nilai akhir yang telah diperoleh guna mempermudah dalam pengambilan keputusan serta meningkatkan kinerja dari setiap relawan. Luaran dari penilitian ini berupa aplikasi d yang dapat melakukan penilaian kinerja secara otomatis untuk dapat melakukan evaluasi terhadap kinerja karyawan.
\end{abstract}

Kata Kunci : Relawan, GRS, Penilaian Kinerja

\begin{abstract}
Performance appraisal is an assessment made to the company's management, both employees and managers who have been doing their jobs. Bulan Sabit Merah Indonesia or BSMI is an organization engaged in the field of humanity. Currently BSMI Surabaya still does not have a volunteer performance appraisal system and lack of evaluation for performance appraisals that can make volunteers to make mistakes or not implement tasks according to the training or training that has been taught previously without paying attention to the rules that have been set. Based on these problems, a website-based volunteer performance appraisal application solution is proposed using the Graphic Rating Scales (GRS) method, which is an assessment method that divides 5 categories of assessment for each assessment factor, the assessment with this method is in accordance with the needs of the organization. The application can find the total value for every 3 events from the volunteer and show a graph of the volunteer's performance from year to year to evaluate and see the increase or decrease in the performance of volunteers and there is a final report feature in the form of a ranking of all volunteers in the order of the final scores that have been obtained to make it easier in decision making and improve the performance of each volunteer. The output of this research is in the form of an application that can perform performance appraisals automatically to be able to evaluate employee performance.
\end{abstract}

Keywords: Volunteer, Graphic Rating Scale, Performance evaluation. 
Yudistira Yusonanda, dkk/ Journal of Technology and Informatics (JoTI), Vol.2, No.2, April 2021, Hal 89-95

\section{PENDAHULUAN}

Bulan Sabit Merah Indonesia Surabaya (BSMI) adalah sebuah organisasi yang bergerak di bidang kemanusiaan yang berlokasi di Jl. Mojo III No. 33 Surabaya. Sampai saat ini BSMI memiliki jumlah cabang sebanyak 13 cabang tingkat provinsi dan 130 cabang tingkat kota/kabupaten. Sehingga, dalam penelitian ini hanya BSMI cabang Surabaya saja yang menjadi subjek penelitian.

Pada saat ini BSMI Cabang Surabaya mempunyai suatu masalah yaitu tidak memiliki sistem penilaian kinerja relawan serta kurangnya evaluasi untuk penilaian kinerja yang bisa membuat para relawan dapat melakukan kesalahan-kesalahan atau tidak menerapkan tugas sesuai diklat atau pelatihan yang telah diajarkan sebelumnya tanpa memperhatikan aturan yang telah ditetapkan. Penilaian kinerja dibutuhkan untuk mengetahui seberapa jauh seorang relawan berhasil atau tidaknya dalam menjalankan tugas dengan baik dan sesuai dengan aturan yang telah ditetapkan selama berada di lokasi bencana atau masalah sosial lainya dan melakukan evaluasi kinerja relawan juga sangat dibutuhkan mengetahui relawan mana saja yang kurang kinerjanya atau kurang berkompeten. Menurut [1] penilaian kinerja adalah suatu penilaian yang dilakukan kepada pihak manajemen perusahaan baik para karyawan maupun manajer yang selama ini telah melakukan pekerjaannya.

Penilaian kinerja merupakan proses yang dilakukan perusahan dalam melakukan evaluasi dan penilaian kinerja karyawan [2],[3]. Terdapat berbagai metode dalam melakukan penilaian kinerja salah satunya dengan menggunakan metode Key Performance Indicator (KPI). dimana proses penilaiannya dilakukan setiap 3 bulan sekali. KPI kemudian dikumpulkan selama satu tahun kemudian dibuat rata-rata atau rasionya [4]. Pada [5] dilakukan penilaian kinerja karyawan dengan menggunakan metode 360 derajat dimana karyawan dapat memperoleh penilaian dari segala arah yaitu atasan, bawahan serta rekan kerja.

Berdasarkan masalah yang terjadi di BSMI cabang Surabaya tersebut maka perlunya untuk merancang aplikasi penilaian kinerja relawan berbasis website dengan menggunakan metode Graphic Rating Scales (GRS). Menurut [6] Metode GRS adalah metode penilaian yang membagi lima kategori penilaian untuk setiap faktor penilaian, faktor yang dijadikan penilaian harus terukur agar penilaian dapat dilakukan secara objektif. Metode graphic rating scale (GRS) yang dapat mengambil keputusan secara tepat dan akurat [7].

Dengan adanya penilaian kinerja bisa membantu pihak tim manajemen BSMI cabang surabaya untuk mendukung proses penilaian kinerja serta mempermudah tim manajemen dalam melakukan proses memasukan data relawan yang ingin dinilai dimanapun dan kapanpun. Manfaat lainya dengan adanya penilaian kinerja ini yaitu tim manajemen dan relawan dapat mengetahui grafik kinerja relawan dari tahun ke tahun untuk mengevaluasi dan melihat peningkatan atau penurunan kinerja relawan.

\section{METODE}

Metode yang digunakan dalam pengembangan aplikasi penilaian kinerja yaitu metode waterfall dan metode untuk proses penilaian kinerja yaitu metode Graphic Rating Scale.

\section{Waterfall}

Menurut [8], model waterfall adalah model klasik yang bersifat sistematis, berurutan dalam membangun software. Model ini melakukan pendekatan secara sistematis dan berurutan. Disebut dengan waterfall karena tahap demi tahap yang dilalui harus menunggu selesainya tahap sebelumnya dan berjalan berurutan. Berikut ini gambar alur proses pengerjaan menggunakan metode waterfall.

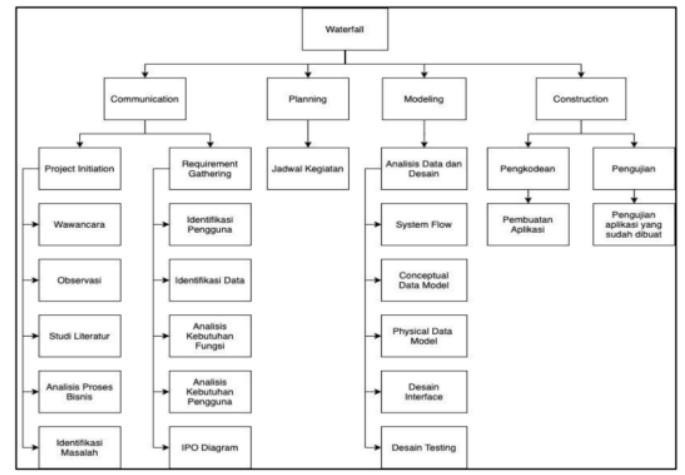

Gambar 1 Alur Proses Pengerjaan Menggunakan Metode Waterfall

\section{Graphic Rating Scale}


Yudistira Yusonanda, dkk/ Journal of Technology and Informatics (JoTI), Vol.2, No.2, April 2021, Hal 89-95

Metode GRS adalah metode penilaian yang membagi lima kategori penilaian untuk setiap 91ystem penilaian, 91ystem yang dijadikan penilaian harus terukur agar penilaian dapat dilakukan secara objektif. Lima 91ystem itu adalah: Sangat buruk, buruk, sedang, baik, dan sangat baik [6]. Penilaian dengan metode ini sendiri bisa dimodifikasi sesuai dengan kebutuhan di Bulan Sabit Merah Indonesia Cabang Surabaya. Modifikasi tersebut bisa berupa jumlah kriteria, subkriteria, pertanyaan, bobot nilai kriteria. Perhitungan rumus untuk hasil penilaian dalam metode Graphic Rating Scale (GRS) adalah sebagai berikut :

$$
N V=\left(\frac{N I 1+N I 2+N I n}{n}\right) \times \text { Bobot Variabel } \times 100 \ldots 1
$$

Keterangan :

$\mathrm{NV}=$ Nilai Variabel

Nin = Nilai Indikator ke-n.

$\mathrm{n}=$ Jumlah 91ystem91 an dalam satu variable.

$$
N A=N V 1+N V 2+N V n \ldots \ldots \ldots \ldots \ldots \ldots . . . . .2
$$

Keterangan :

$\mathrm{NA}=$ Nilai Akhir

$\mathrm{NVn}=$ Nilai variable ke-n.

Penjelasan dalam penerapan penilaian kinerja dengan metode Graphic Rating Scale yang dinilai pada relawan :

1. Bobot pada penilaian ditentukan berdasarkan tingkat kepentingan atau prioritas perusahaan/organisasi sesuai dengan level jabatan yang sudah ditentukan.

2. Total bobot pada penilaian harus berjumlah 100

3. Penilaian dimulai dari angka 1 sampai dengan 4

4. Parameter yang digunakan adalah hasil konversi nilai akhir yang telah dilakukan setiap relawan dalam $3 \mathrm{x}$ tahapan penilaian. Parameter konversi nilai A dan B yang akan dipertimbangkan terlebih dahulu untuk tim manajemen dalam menentukan relawan yang akan diterjunkan System dan relawan yang mendapatkan nilai akhir konversi parameter A yang akan dipertimbangkan terlebih dahulu untuk promosi jabatan.

Tabel 1 Penjelasan Angka Penilaian :

\begin{tabular}{ll}
\hline \multicolumn{2}{c}{ AngkaPenilaian } \\
\hline Sangat Baik
\end{tabular}

\begin{tabular}{cc} 
Baik & 3 \\
Cukup & 2 \\
Buruk & 1 \\
\hline
\end{tabular}

\section{Communication}

Tahap communication adalah sebuah tahap awal untuk mengkomunikasikan pekerjaan yang akan dilakukan. Tahap komunikasi ini digunakan untuk memperoleh spesifikasi kebutuhan awal dari aplikasi yang akan dikerjakan.

\section{Analisis Proses Bisnis}

Proses bisnis pemilihan relawan dimulai dari tim management memilih relawan untuk dilibatkan dalam suatu kegiatan atau bencana dengan ketentuan awal yaitu memenuhi kriteria, jika memenuhi kriteria maka pihak tim management akan menghubungi relawan tersebut untuk ketersediaan dalam melakukan kegiatan atau bencana kemudian relawan dapat melakukan cek system91 sebagai syarat terakhir dan hasil surat keterangan, system91 harus diserahkan kepada tim management sebagai bukti. Kemudian jika memilih relawan untuk naik jabatan adalah dimulai dari tim management memilih relawan untuk naik jabatan dengan ketentuan awal yaitu mengecek keaktifan, jika aktif maka pihak tim management akan melihat memenuhi kriteria atau tidak dari relawan tersebut untuk dinaikkan jabatanya lalu tim management akan melakukan pengambilan keputusan.

\section{Planning}

Dalam tahap perencanaan memuat tentang rencana dan jadwal pengerjaan pengembangan aplikasi penilaian kinerja relawan dari tahap perencanaan, perancangan dan pembuatan aplikasi.

\section{Modeling}

Pada tahap ini memuat tentang analisis sistem dan perancangan pengembangan aplikasi penilaian kinerja relawan. Pada tahap analisis sistem akan dilakukan analisis kebutuhan pengguna, analisis kebutuhan fungsional, analisis kebutuhan non-fungsional, analisis kebutuhan 91ystem. Sedangkan pada tahap perancangan akan dilakukan tahap tahap System Flowchart, diagram IPO (Input-Process-Output), Diagram berjenjang, Context Diagram, Entity Relationship Diagram, Struktur Tabel, Desain antarmuka pengguna dan Desain Testing. 


\section{System Flowchart}

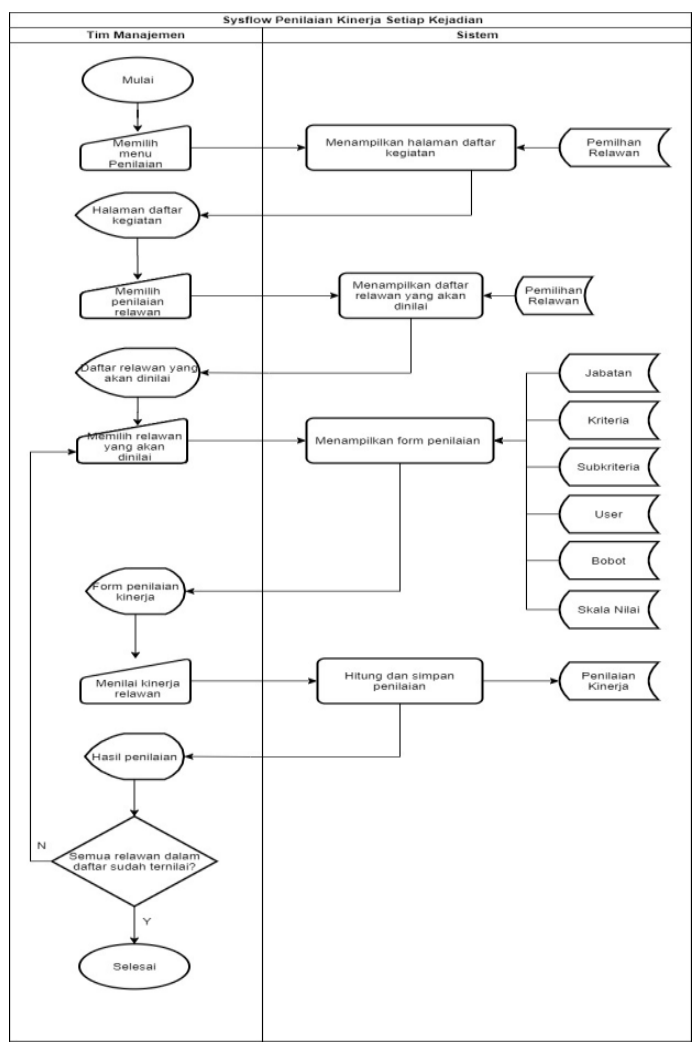

Gambar 2 System Flowchart Penilaian Kinerja Setiap Kejadian

Pada tahap system flowchart dilakukan perancangan bagan alur sistem yang akan dibuat, terdiri dari pengelolaan data, penilaian kinerja, penilaian kinerja akhir atau 3 kegiatan dan laporan penilaian kinerja.

Berikut ini system flowchart dari proses penilaian kinerja setiap kejadian:

System Flowchart penilaian kinerja diawali dengan proses tim management memilih nama relawan mana yang akan di nilai berdasarkan database nama relawan di pemilihan relawan. Kemudian 92ystem akan menampilkan form penilaian yang perlu tim management isi kemudian melakukan klik tombol simpan. Sistem akan menyimpan ke dalam database dan 92ystem telah menyimpan data penilaian dari relawan yang telah dipilih oleh tim management. Setelah itu tim management mengecek apakah semua relawan sudah dinilai? Jika belum maka akan dilakukan kegiatan yang sama dan jika sudah maka selesai. Kemudian berikut system flowchart dari proses penilaian kinerja 3 kejadian atau akhir.

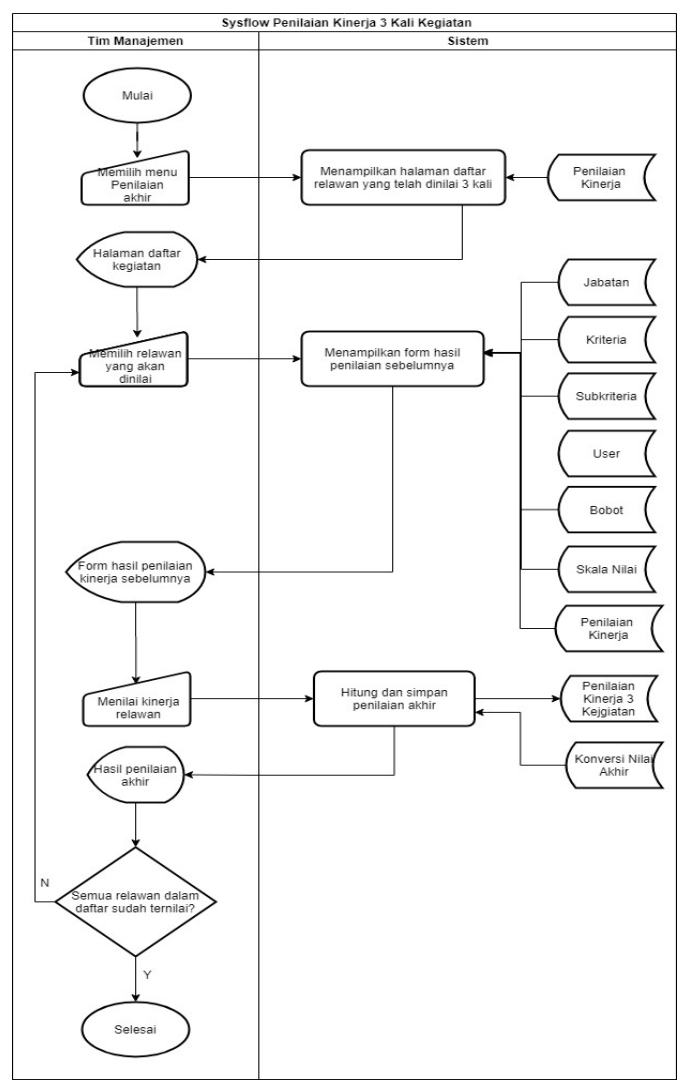

Gambar 3 System Flowchart Penilaian Kinerja 3 Kegiatan

System Flowchart penilaian kinerja 3 kejadian diawali dengan proses tim management memilih nama relawan mana yang akan di nilai akhir berdasarkan penilaian sebelumnya. Kemudian 92ystem akan menampilkan form penilaian yang sebelumnya. Tim management kemudian menilai dan 92ystem akan menghitung dan menyimpan penilaian akhir ke dalam database. Setelah itu tim management mengecek apakah semua relawan sudah dinilai akhir? Jika belum maka akan dilakukan kegiatan yang sama dan jika sudah maka selesai.

\section{Diagram Berjenjang}

Diagram berjenjang dalam proses pengembangan aplikasi penilaian kinerja relawan pada Bulan Sabit Merah Indonesia Cabang Surabaya memiliki 3 bagian proses yaitu data master, data transaksi dan pembuatan laporan. Berikut ini merupakan gambar diagram jenjang aplikasi penilaian kinerja relawan: 
Yudistira Yusonanda, dkk/ Journal of Technology and Informatics (JoTI), Vol.2, No.2, April 2021, Hal 89-95

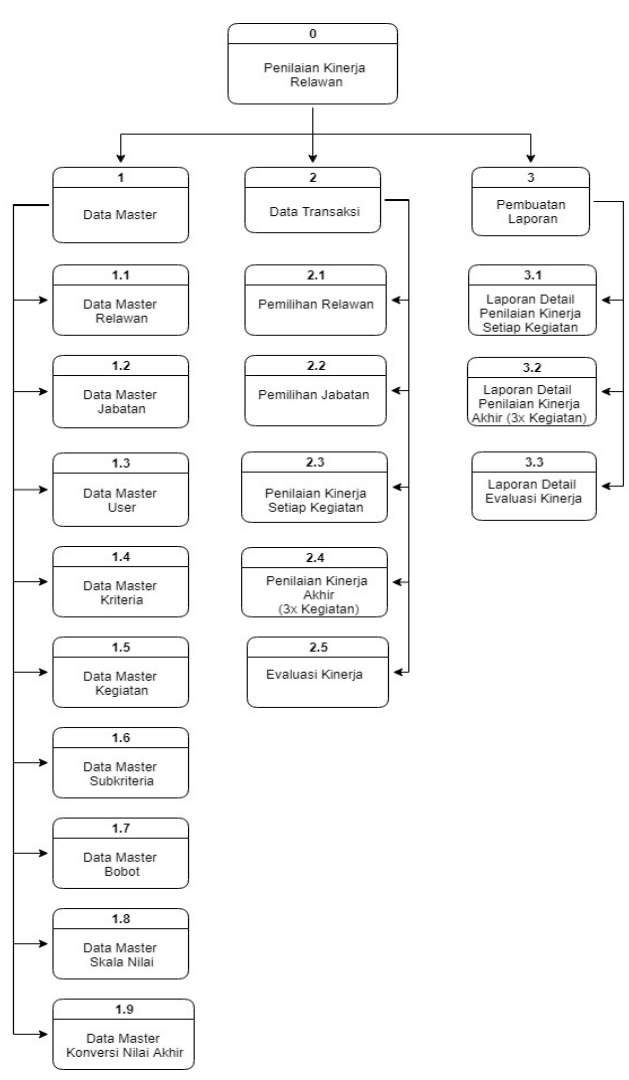

Gambar 4. Diagram Berjenjang

\section{Context Diagram}

Context diagram[9],[10] dari aplikasi penilaian kinerja relawan pada Bulan Sabit Merah Indonesia Cabang Surabaya memiliki 3 entitas yaitu entitas unit sekretaris, entitas tim manajemen dan entitas relawan. Berikut gambar dari context diagram aplikasi penilaian kinerja relawan

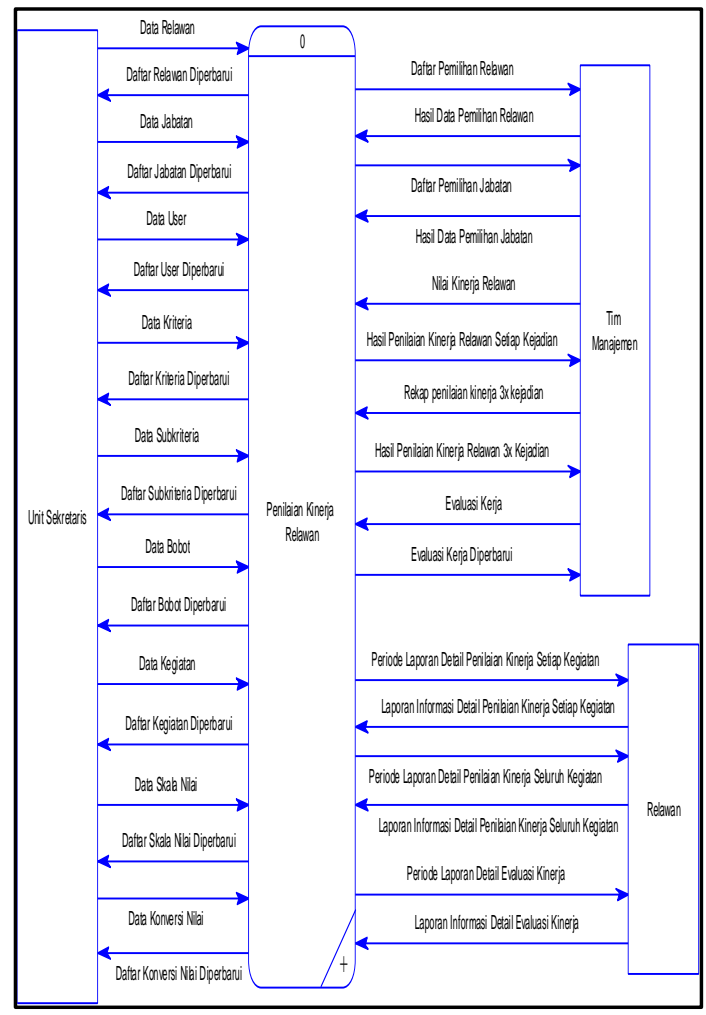

Gambar 5 Context Diagram

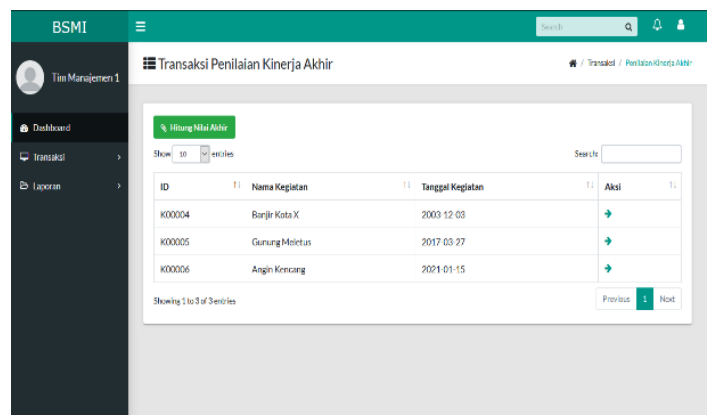

\section{HASIL DAN PEMBAHASAN}

Berikut merupakan implementasi aplikasi penilaian kinerja sesuai dengan rancangan yang telah dibuat sebelumnya. 
Yudistira Yusonanda, dkk/ Journal of Technology and Informatics (JoTI), Vol.2, No.2, April 2021, Hal 89-95

\section{Halaman Penilaian Kinerja}

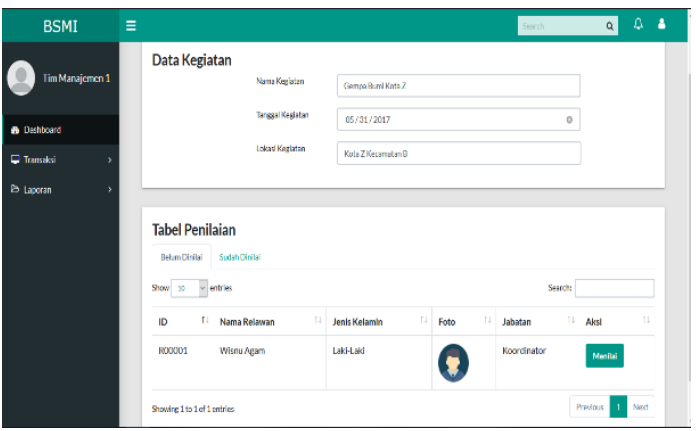

Gambar 6 Halaman Penilaian Kinerja

Gambar diatas merupakan tampilan halaman penilaian kinerja. Pengguna memilih jendela belum dinilai lalu menekan tombol menilai untuk memulai proses penilaian kinerja.

Saat pengguna menekan tombol menilai sistem menampilkan form penilaian kinerja sesuai. Pengguna memasukkan data sesuai dengan list yang ada pada form tersebut. Sedangkan untuk kode penilaian kinerja ditampilkan secara otomatis oleh sistem sesuai dengan urutan data yang telah tersimpan.

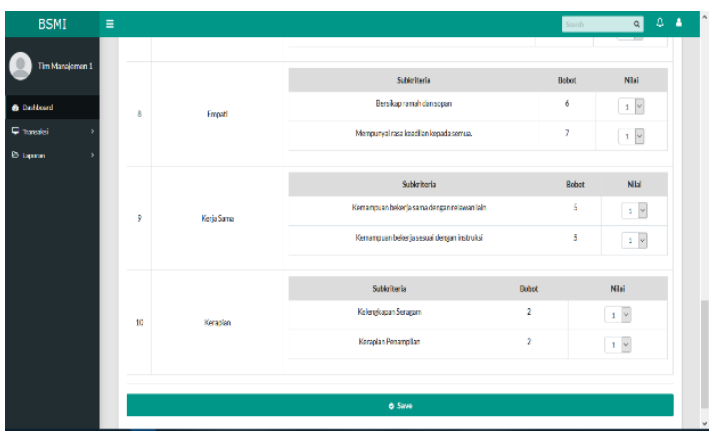

Gambar 7 Form Penilaian Kinerja

\section{Halaman Penilaian Kinerja Akhir}

Gambar dibawah merupakan tampilan halaman penilaian kinerja akhir. Pengguna memilih relawan mana yang ingin dinilai akhir dengan total 3 kegiatan lalu menekan tombol hitung nilai akhir untuk memulai proses penilaian kinerja akhir.

\section{Gambar 8 Halaman Penilaian Kinerja Akhir}

Saat pengguna menekan tombol hitung nilai akhir sistem menampilkan form penilaian kinerja akhir yang telah di rata-rata dan di total setiap subkriteria

Gambar 9 Form Penilaian Kinerja Akhir 1

Gambar 10 Form Penilaian Kinerja Akhir 2

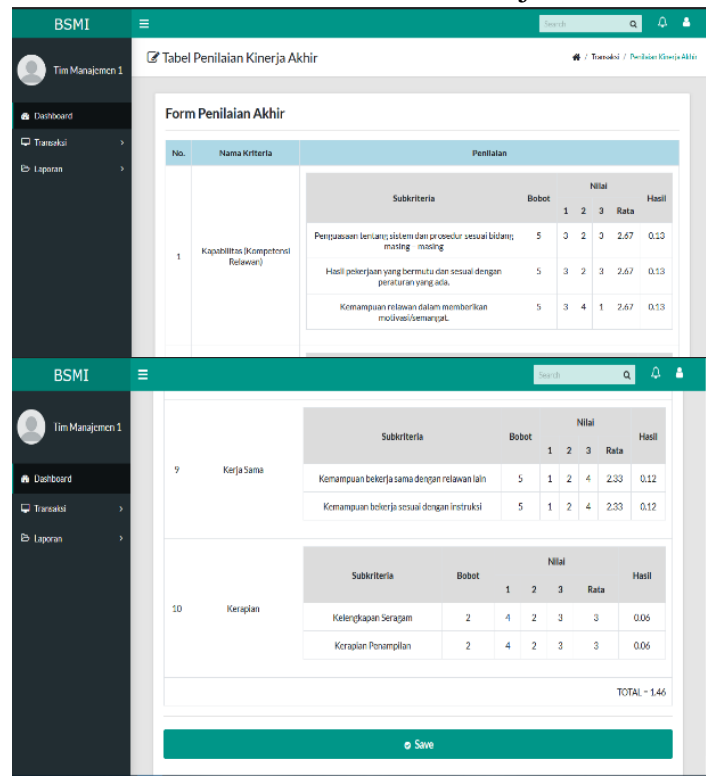

Setelah pengguna melakukan proses penyimpanan maka sistem memperbarui list data dan menampilkan total penilaian akhir sesuai dengan metode Grpahic Rating Scale (GRS) dan menampilan keterangan beserta grafik dari setiap kegiatan.

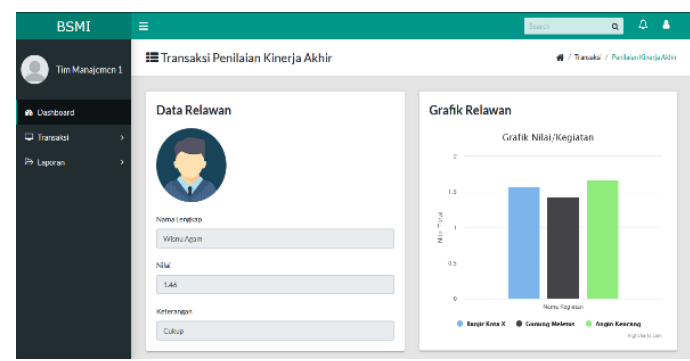

Gambar 11 Form Informasi Detail Penilaian Kinerja Akhir

Berdasarkan hasil yang diperolah yaitu sistem penilaian kinerja dapat melakukan proses penilaian kinerja para karyawan menggunakan metode GRS yaitu melakukan penilaian akhir atau penilaian dalam setiap 3 kali kegiatan dilanjutkan dengan proses evaluasi kinerja yang didukung dengan tampilan visual berupa grafik rata-rata per kegiatan. 
Yudistira Yusonanda, dkk/ Journal of Technology and Informatics (JoTI), Vol.2, No.2, April 2021, Hal 89-95

\section{KESIMPULAN DAN SARAN}

Berdasarkan semua tahapan yang sudah dilakukan yaitu Communication, Modeling, Planning, dan Construction, maka dapat diperoleh beberapa kesimpulan sebagai berikut:

1. Hasil penelitian berupa penilaian kinerja yang dapat melakukan proses penilaian kinerja relawan menggunakan metode Graphic Rating Scale (GRS) untuk melakukan penilaian akhir atau penilaian di 3 kali kegiatan sehingga dapat diketahui apakah relawan sudah melakukan tugasnya dengan baik atau tidak.

2. Aplikasi penilaian kinerja dapat menampilkan dalam bentuk visualisai data grafik sehingga mudah dipahami dalam membaca data dan juga memudahkan untuk evaluasi para relawan sehingga dapat menjadi pertimbangan bagi pihak manajemen untuk melakukan pemilihan relawan pada kegiatan selanjutnya.

\section{Ucapan Terimakasih}

Penulis berterima kasih kepada pihak Bulan Sabit Merah Indonesia Surabaya yang telah membantu penulis untuk menyelesaikan penelitian ini atas ijin dan data yang telah diberikan kepada penulis.

\section{DAFTAR PUSTAKA}

[1] Fahmi, Irham. 2014. Analisis Laporan Keuangan. Bandung: Alfabeta.

[2] Hanggraeni,D .2012, Manajemen Sumber Daya Manusia, Lembaga Penerbit Fakultas Ekonomi Universitas Indonesia, Jakarta.

[3] Notoatmodjo,S. 2009, Pengembangan Sumber Daya Manusia, Rineka Cipta, Jakarta.

[4]Setiabudi,S . (2017). Analisis Sistem Penilaian Kinerja Karyawan Studi Kasus pada PT. Tridharma Kencana. Journal of Applied Business and Economics, vol 3 no 3

[5] Susanto,S., Andriana, A.D. Analisis Metode 360 Derajat untuk Penilaian Kinerja Karyawan pada Sistem Informasi Manajemen Sumber Daya Manusia. Majalah Ilmiah UNIKOM. Vol.17 no 1
[6] Bangun, Wilson. 2012. Manajemen Sumber Daya Manusia. Jakarta : PT. Glora Aksara Pratama

[7] Wahyuning,H. 2015. Sistem Pendukung Keputusan Mutasi Anggota Kepolisian Polresta Palembang Dengan Menggunakan Metode Graphic Rating Scal. Jurnal Sistem Informasi : 1-11

[8] Pressman, R. (2015). Rekayasa Perangkat Lunak - Buku Satu, Pendekatan Praktisi Buku I. Yogyakarta: ANDI.

[9] Afyenni, R. (2014). Perancangan Data Flow Diagram Untuk Sistem Informasi Sekolah. TEKNOIF, Vol. 2 No., 1-3.

[10] Doro, E., \& BetshaniStevalin. (2009). Analisis Data dengan Menggunakan Entity Relationshp Diagram (ERD) dan Model Konseptual Data Warehouse. Informatika, Vol. 5 No., 75-85 